\title{
Pazarlama İletișimi Acısından İnternet Ortamında Kullanılan Ağızdan Ağıza Pazarlama Tekniklerinin Marka Tercihine Etkisi
}

\section{The Effect Of E-Womm Methods On Brand Preferences Through Marketing Communications Framework}

\author{
Nihal TOROS DAPIAPIS ${ }^{* *}$
}

Özet

Pazarda her geçen gün artan marka saylsı tüketicinin tercihini zorlaştırırken, üreticinin/marka sahibinin de rakipleri arasında fark edilmesini güçleştirmektedir. Piyasada yaşanan bu değişimler sonucunda işletmeler geleneksel pazarlama anlayışlarından uzaklaşarak, tüketicilerin istek ve ihtiyaçlarına odaklanan bir pazarlama anlayışına yönelmişlerdir. Diğer yandan dijital medyada yaşanan gelişmeler buranın bir pazarlama mecrası olarak görülmesine de olanak sağlamıştır. Tüketicilerin gücünün farkına varmış, yenilikçi, yaratıcı ve çağdaş işletmeler, özellikle dijital ortamda ă̆ızdan ă̆ıza pazarlama uygulamalarıyla birlikte, yarattıkları pazarlama mesajlarının yayılmasında tüketicilerin de desteğini alarak bu sürece dahil olmalarına imkan vermiş, böylelikle kendilerini işletmenin bir parçası olarak hissetmelerini sağlayarak, aralarında sağlam bir güven duygusu ve bağ gelişstirmiştir. Tüketicilerin üreticilerden daha fazla söz sahibi olduğu, yaratıcı gücün ön plana çıktığl, sadece gerçek fikirlerin

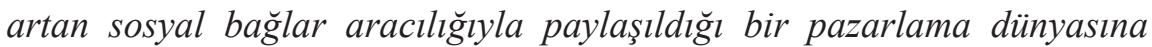
yöneliş başlamıştır.

${ }^{(*)} Y r d$. Doç. Dr. Üsküdar Üniversitesi, İletişim Fakültesi, Medya ve İletişim Sistemleri Bölümü Öğretim Üyesi.E-mail: nihal.toros@uskudar.edu.tr 


\section{Nihal TOROS DAPIAPIS}

Üsküdar University Journal of Social Sciences

Year:1

Issue:1

Anahtar Sözcükler: Ăğzdan ă̆ıza pazarlama, Elektronik ă̆ızdan ağıza pazarlama (e-WOMM), Dijital pazarlama, Pazarlama iletişimi, Marka tercihi

\section{Abstract}

The increasing number of brands in the market makes it difficult for the customer to choose, also makes it difficult for the producers being noticed among its competitors. Due to these changes in the market, the corporations became distanced to traditional marketing concept and tended to a consumer oriented marketing concept which focuses on consumer needs and wants. The developments in digital media enabled it to be used as a marketing medium. The innovative, creative and contemporary corporations have noticed the consumer power. They built a bond among their consumers with the word of mouth (e-WOM) practices in the new media. These companies get the help of their consumers during the transmission of their marketing messages and also give them a chance to be part of the corporation which leads to strong trust and bond among them. A new marketing world, where the customers have more to say than the producers, the innovative power is important and only real ideas are shared through social ties, has been established.

Keywords: Word of mouth marketing, Electronic word of mouth marketing (e-WOMM), Digital marketing, Marketing communications, Customer preferences

\section{Giriș}

Günümüzde yaşanan enformasyon çağ1 ile güç, büyük şirketlerin ve sosyal kurumların elinde olmaktan çıkıp tüketicilerin eline geçmektedir. Bireysel tüketicilerin dev şirketleri sarsmak, istekleri için politikacılara bask1 yapmak, pazarda daha fazla pazarlık gücüne sahip olmak ve medyada yer alanlara yön verebilmek üzere güç kazanması söz konusudur. Bu çerçevede, her geçen gün piyasaya bir yenisinin girdiği markalar dünyasında tercih edilir olmak ya da ayakta kalmak giderek zorlaşmaktadır. Sektörlerin gittikçe artan 
bir rekabet yaşadığı internet ortamında hazır giyim sektöründe de rekabet giderek kızışmakta, yerli markaların yanında uluslararası markalar pazarda önemli bir yer tutmaktadırlar. Bu rekabet ortamında ürettikleri ürünleri pazarlayabilmek için pazarlamacılar yeni tekniklerden yararlanmak ve rakiplerinden bir adım önde olmak zorundadırlar. Dünyanın birleşerek tek bir Pazar haline gelmesi olarak tanımlayabileceğimiz küreselleşme, ürünlerin uluslararası boyutta dağıtımını kolaylaştırdığı gibi bilginin de müthiş bir hızla yayılmasına olanak sağlamaktadır. Bu bağlamda küreselleşme daha değişken bir pazar ve rekabet ortamı yaratmaktadır. Bu değişimlere ayak uyduramayan işletmelerin pazarda varlıklarını sürdürmeleri mümkün olamamaktadır. Ekonomide küreselleşme ve iletişim olanaklarının artması işletmelerin iletişimini kolaylaştırırken, karmaşık bir hal alan toplumsal ve ekonomik yapı, kuruluşların seslerini duyurmalarını zorlaştırmaktadır. Kuruluşların daha geniş kitlelerle iletişim kurma zorunluluğu duyması ise, halkla ilişkilere ve yeni yöntemlere duyulan gereksinimi arttırmaktadır. ${ }^{1} \mathrm{Bu}$ bağlamda dijital medya (internet), kuruluşların hedef kitleleriyle iletişim kurmalarını çabuklaştıran ve kolaylaştıran bir araç olarak karşımıza çıkmaktadır.

Burada temel bir sistemi tanımlamak gerekmektedir. Bu, yukarıda bahsedilen birçok gelişimi çerçeveleyen, onun dinamizmini ve sürekliliğini belirleyen temel bir sistemdir ve esas olarak şu parça ve süreçlerden oluşmaktadır: 1- Teknolojik Gelişim: Bu, internetin kullanıma açılması ve kişisel bilgisayarlarla bireylerin de bu evrene dahil olma sürecidir. Süreç, internetin yaygınlaşmaya başladığı 1990'lardan bugüne akıllı cep telefonları, tablet vb. kişisel teknolojik araçlarla daha da çok gelişmekte, genişlemekte ve tabansallaşmaktadır. 2- Tüketicinin bu evrene giriş anahtarı olan kredi kartlarının varlığı ve sanal ödeme olanaklarının gelişmesi ve yaygınlaşması. Nitekim kredi kartı ve sanal ödeme sistemlerinin olmadığı bir ortamda ticaret, pazarlama faaliyetlerinin yapılması oldukça zor olacaktır. $\mathrm{Bu}$ da sistemin işleyiş hızını ve yoğunluğunu, dolayısıyla gelişimini olumsuz şekilde etkileyecektir. Sistem, finansman ve ödeme ağıyla eklemlendikçe büyümektedir. İçinde tüketicinin ve endüstrilerin de yer aldığı internet ortamı e-iş, e-ticaret, e-WOMM vb. çeşitli boyutlarıyla

\footnotetext{
${ }^{1}$ Filiz Balta Peltekoğlu, Halkla İlişkiler Nedir?, 5.Baskı, (İstanbul: Beta Basım A.Ş. 2007), ss.306-307.
} 


\section{Nihal TOROS DAPIAPIS}

bu temel sistem içinde yer almaktadır. Bu çerçeveye bloglar, tüketici siteleri, çeşitli platformlar ve Facebook gibi sosyal ağların eklemlenmesi ile günümüzde pazarlama iletişimi, internet ortamında oldukça interaktif, çift yönlü iletişime dönük bir hal almıştır.

Kalkınma Bakanlığı Bilgi Toplumu Dairesi ve Mc Kinsey'in 2013 Şubatında yayınladığı raporda ise küresel e-ticaret hacminin 2012 yılında 1,5 trilyon dolara ulaştığı belirtilmektedir. ${ }^{2}$ Tüketicinin elindeki yeni kuşak teknolojiyi ifade eden mobil teknoloji kullanımı ile alışverişin ise Avrupa'da 2013 yaz dönemi itibariyle bir önceki yılın aynı dönemine göre yüzde 43 arttığ 1 saptanmıştır ve genel mobil alışveriş kategorilerine bakıldığında moda, yüzde $78^{\prime}$ lik bir oran ile mobil alışverişin önemli bir kalemidir. ${ }^{3}$

Türkiye'deki elektronik haberleşme sektöründe faaliyet gösteren

Üsküdar University Journal of Social Sciences

Year:1

Issue:1

işletmelerin, Bilgi Teknolojileri ve İletişim Kurumu'na göndermiş oldukları veriler esas alınarak hazırlanan raporda 2013 y1lı Q2 dönemine ait verilere göre 2013 yılı sonu itibariyle geniş bant internet abone sayısı 20 milyon 573 bini geçmiştir. ${ }^{4}$ Bilgi Teknolojileri ve İletişim Kurumu verilerine göre; Türkiye'deki internet kullanıcı sayısı ise 50 milyon kişi olarak hesaplanmış olup, bunun toplam nüfusa oranı yüzde $65^{\prime}$ dir. Bu sayı ile Türkiye dünyada 12'nci, Avrupa'da ise 4'üncü sırada yer almaktadır. Türkiye'de her ay eklenen yeni internet kullanıcısı sayıs1 90 bin'dir ve Türkiye ortalama internet kullanım saati olarak Avrupa'da 1. siradadır. ${ }^{5}$

Türkiye'de kullanıcıların internet üzerinde yaptıkları ödeme hacmi ise dünyadaki son üç yıllık trendden daha hızlı bir şekilde gelişmiştir. MasterIndex araştırmasına göre, Türk halkının cebinde 1,6 adet kredi kartı bulunmaktadır ve hem kredi kartı hem banka kartı bulunan tüketicilerin

2 "Kalkınma Bakanlığı internet girişimciliği ve e-ticaret raporu yayınladı", E-Ticaret Mag, 6 Şubat 2013, Erişim 2 Mart 2015,

http://eticaretmag.com/kalkinma-bakanligi-internet-girisimciligi-ve-e-ticaret-raporu-yayinladi/

${ }_{3}^{3}$ Amy Dusto, "43 \% more Europeans shop via mobile this year", 24 Ekim 2013, Erişim 5 Mart 2015, https://www.internetretailer.com/2013/10/24/43-more-europeans-shop-mobile-year

4 "Internet ve mobil Pazar istatistikleri-2013 Q2 Türkiye Raporu", 20 Eylül 2013, Erişim 5 Mart 2015, http://www.connectedvivaki.com/turkiyede-internet-ve-mobil-pazar-istatistikleri-btk-2013-q2-raporu

5 "Türkiye genel internet verileri", Erișim 7 Mart 2015,

http://www.eticad.org.tr/bilgi-merkezi/sektorel-bilgiler/turkiye-genel-internet-verileri/ 
oranı yüzde $36^{\prime}$ dır. $^{6} \mathrm{Bu}$ durum, internet üzerinden pazarlama ve satın alma potansiyelinin bulunduğunu, tüketicinin internet evrenine e-alışveriş bağlamında girebilmek için temel finansman araçlarına önemli ölçüde sahip bulunduğunu göstermektedir. Bunun yanısıra Bankalararası Kart Merkezi (BKM) verilerine göre, 2009-2012 yılları arasında dünyada ödeme hacmi yüzde 16 artarken bu oran Türkiye'de yüzde 41 artmıştır. 2013 yılında ülkede 150 milyona yakın internetten ödeme yapılırken 2010 yılında 75 milyon işlem yapılmıştır ki bu tablo, oranın günümüzde ikiye katlandığını göstermektedir. Mevcut kredi kartlarının üçte birinden fazlası sanal poslarda kullanılmış, toplamda 56 milyon kredi kartının 20 milyonu ile internetten ödeme yapılmıştır. 2016 yılında dünyada internet ekonomisinin 4,2 trilyon dolara ulaşması beklenmektedir. ${ }^{7}$ İşletmeden tüketiciye e-ticaretin toplam ticaret içindeki payı yüzde 1,7 olmasına rağmen ${ }^{8}$ bu sürecin gelişmekte olduğu gözlemlenmektedir.

Türkiye' deki yüksek cihaz fiyatları, mobil cihaz ve uygulama pazarının küresel pazarları gecikmeli olarak takip etmesine neden olmaktadır; fakat fiyatın belli bir eşik değerin altına inmesiyle akıllı telefonların pazardaki payı 2012'de yüzde 14 seviyesine ulaşmıştır. ${ }^{9}$ Bu noktada Türkiye'de de yukarıda bahsettiğimiz küresel temel sistemin teknoloji, kredi kartı ve ödeme araçları boyutlarıyla gelişmekte olduğunu gözlemlemek mümkündür. $\mathrm{Bu}$ genel tablo içinde, inceleme kapsamında ele aldığımız giyim sektörü Türkiye'de e-ticaret bağlamında oldukça gelişmekte olan bir sektör olarak göze çarpmaktadır. Türkiye İstatistik Kurumu (TÜİK) tarafından yapılan araştırmada e-ticaret harcaması yapılan sektörlerin başında giyim, elektronik eşya (bilgisayar ile birlikte) ve ev eşyaları geldiği görülmektedir. Giyim ve spor malzemeleri yüzde 44,4 oran ile internetten en çok alışveriş yapılan kategoriler olmuştur. ${ }^{10}$

6"MasterIndex, (2011) Aralık 2011 Araştırma Sonuçları", 16 Nisan 2012, Erişim 25 Mart 2013, http://www.mastercard. com/tr/personal/tr/promotions/MasterIndexARALIK2011Banka.pdf

${ }^{7}$ Hilmi Öğütçü, "2009 - 2013 Yılları Arası Türkiye E Ticaret Büyüme Oranı ve Hacmi”, 18 Mayıs 2014, Erişim 12 Şubat 2015,

http://www.egirisim.com/2009-2013-yillari-arasi-turkiye-e-ticaret-buyume-orani-ve-hacmi/

8 "Kalkınma Bakanlığ internet girişimciliği..."

${ }_{9}$ T.C.Kalkınma Bakanlığı, Bilgi Toplumu Stratejisinin Yenilenmesi Projesi, Internet Girişimciliği ve e-Ticaret Ekseni Mevcut Durum Raporu, 10 Nisan 2013, s.115.

${ }^{10}$ A.g.e., s. 122. 


\section{Nihal TOROS DAPIAPIS}

Öte yandan pazarda oluşan değişimlere bakıldığında, öncelikle iç ve dış rekabetin artması, buna karş11ı pazar büyümesinin yavaşlaması, ürün hayat eğrisinin kısalması, tüketicinin bilinçlenmesi, daha seçici olması ve fiyat duyarlılı̆̆ının artması, sektördeki marka sayısının artması, rakiplerden gelen niş saldırılar, satış gücü maliyetlerinin yükselmesi, rekabet avantajlarının ancak kısa süreler için sağlanabilmesi, promosyon maliyetlerinin artmasına rağmen promosyon etkinliğinin azalması, tüketicinin farklı markalar arasında fark görmemesi ${ }^{11}$ gibi nedenler pazarın dinamiğini değiştirmiş, pazarlamada yeni tekniklerin uygulanmasını zorunlu kılmıştır.

Piyasada olan bu değişimler tüketicinin rolünün de büyük ölçüde değişmesine neden olmuş, geçmişte kendisine ne verilirse kabul eden pasif tüketici profili yerini, pazara hakim olma isteği ve gücüne sahip aktif tüketici profili almıştır. Günümüzde pazar bölümlerinin artmas1, tüketicilerin marka ve ürüne bağımlılıklarının azalması, tüketicideki hizmet

Üsküdar University Journal of Social Sciences

Year:1

Issue:1 beklentisinin yükselmesi, pazardaki kutuplaşma, tüketicinin daha seçici hale gelmesi, bilinçlenmesi, global alışveriş imkanlarının yaygınlaşması, online alışverişin yaygınlaşması, tüketicinin üzerindeki zaman baskısı gibi nedenlerle alışverişe daha az zaman ayırmalar $1^{12}$ tüketicilerin değişen yapısının özellikleri olarak karşımıza çıkmaktadır. Bu yeni yapı satın alma karar süreci üzerinde doğrudan etkili olduğundan, pazarlama faaliyetlerinin de bu özelliklere göre şekillenmesi gerekmektedir.

1980'li yıllarla birlikte uygulanmaya başlanan, temelinde üretim bazlı pazarlama anlayışını sorgulayan ve müşteri/olası müşterilerin talep ve beklentilerini merkeze alan yeni pazarlama anlayış ${ }^{13}$ günümüzde dijital medyayı kullanarak müşterileriyle daha hızlı ve etkin iletişim kurarak kitlesel pazarlamadan uzaklaşıp kişiye özel ve daha etkili pazarlama programlarına yönelen bir yaklaşım halini almıştır. Çünkü günümüz müşterileri, geleneksel pazarlama yöntemlerini ve kanallarını çok iyi tanımakta, bu kanalları nasıl reddetmeleri gerektiğinin de bilincindedirler.

\footnotetext{
${ }^{11}$ Selma Özçoban, "Türk Hazır giyim Ürünlerinin Pazarlarda Yer Almasında Marka İmajı Yaratmanın Önemi ve Sarar giyim A.Ş. ye ait Uygulama", Anadolu Üniversitesi Sosyal Bilimler Enstitüsü, Basılmamış Yüksek Lisans Tezi, 2003, Eskişehir, s.50.

${ }^{12}$ A.g.e, s.53.

${ }^{13}$ İzzet Bozkurt, İletişim Odaklı Pazarlama, (İstanbul: Media Cat 2004), s.22.
} 
Ağızdan Ağıza Pazarlama Tekniklerinin Marka Tercihine Etkisi

$\mathrm{Bu}$ nedenle kuruluşlar geleneksel pazarlama yöntemleri aracıllı̆ıyla hedef kitlelerine ulaşmak ${ }^{14}$ ve tüketicilerin dikkatini çekmekte zorlanmaktadırlar. $\mathrm{Bu}$ durum, pazarlamada alternatif yöntemlere yönelmeyi gerekli hale getirmektedir. $\mathrm{Bu}$ bağlamda günümüzün vazgeçilmez iletişim aracı olan internette yani dijital ortamda ağızdan ağıza pazarlama, diğer bir değişle elektronik ağızdan ağıza pazarlama, pazarda rakiplerden bir adım önde olabilmek ve tüketicilerle sürekli iletişimde olabilmek için bir gereklilik haline gelmiştir.

\section{Literatür Taraması}

Web tabanlı tüketici iletişim platformları ve internet, tüketicilerin mal ve hizmetlerle ilgili deneyimlerini diğer tüketicilerle paylaşmalarına olanak sağlamaktadır. Bu paylaşmaya elektronik/dijital ağızdan ağıza pazarlama ya da e-WOMM denilmektedir. Yapılan araştırmalarda tüketicilerin dijital ortamda ağızdan ağıza pazarlamaya yönelmelerinde sosyal etkileşim, ekonomik teşvikler, diğer tüketicilere karşı duyulan sorumluluk, kendini değerli hissetme ihtiyacı gibi güdülerin etkisi olduğu görülmektedir.

Dijital ortamda ağızdan ağıza pazarlama web tabanlı düşünce platformları, tartışma forumları, boykot web siteleri, haber grupları, sosyal paylaşım siteleri, fisıltı yaratarak pazarlama (buzz pazarlama), e-posta gönderme (e-mailing), reklam amaçlı oyun (advergaming), bloglar, mobil bloglar (mobloglar), videobloglar, wikiler yoluyla gerçekleşmektedir. $\mathrm{Bu}$ dijital ortamlarda kurum ve kuruluşlar marka ve ürünleriyle ilgili bilgileri yayabildikleri gibi tüketiciler de bu marka ve ürünlerle ilgili görüş ve tecrübelerini paylaşabilmekte ve tartışabilmektedirler.

Gündelik yaşamlarında insanlar ürünler, hizmetler ya da markalar ile ilgili konuşur, yorum yapar, değerlendirmelerde ve tavsiyelerde bulunurlar. Tavsiye ağızdan ağıza pazarlamanın temelini oluşturur. Tüketicilerin, ürün ya da hizmetle ilgili herhangi bir bilgi ya da değerlendirmeyi kendilerine yakın olan ya da güvendikleri başka tüketicilerle paylaşmaları, tavsiyede

${ }^{14}$ Justin Kirby, Online Viral Marketing: The Strategic Synthesis In Peer-to-Peer Brand Marketing, Brand Channel White Paper, (Digital Media Communications Ltd. 2004), s.2. 


\section{Nihal TOROS DAPIAPIS}

bulunmaları, satın alma karar aşamasındaki tüketicilerin karar verme sürecini hızlandırdığı gibi, ürünü tavsiye eden kişinin, ürünü satan kuruluşta görev yapmaması nedeniyle diğer pazarlama yöntemlerinden çok daha etkilidir. Ağızdan ağıza pazarlamanın etkisi özellikle tüketicilerin bilgi arayışı, değerlendirme, karar verme süreci gibi davranışları üzerinde görülür. İnternet öncesi dönemde tüketiciler ürün, marka ya da kurumla ilişkili tecrübelerini dostluklar, arkadaşlıklar, aile sohbetleri gibi ortamlarda birbirleriyle paylaşırlar; geleneksel ağızdan ağıza pazarlama gerçekleşirdi. İnsanların birbirlerinden etkilenmelerinin bir dergi, gazete ya da televizyon reklamından etkilenmelerinden dokuz kat daha güçlü olması, ağızdan ağıza pazarlamanın etkinliğini artırmaktadır. İnternetin yaygınlaşmasıyla beraber, internet kendi global dünyasına uygun olarak ağızdan ağıza pazarlamada globalleşmiş, birbirini hiç tanımayan insanlar tüketim tecrübelerini paylaşarak birbirlerine tavsiyelerde bulunur olmuşlardır.

Üsküdar University Journal of Social Sciences Year:1 Issue:1
$\mathrm{Bu}$ süreç içinde, doğal olarak elektronik ağızdan ağıza pazarlama ile geleneksel ağızdan ağıza pazarlama arasında temel bir takım farklar ortaya çıkmıştır:

Ağızdan ağıza pazarlamada verilerin toplanacağı bir ortam yokken internetin sağladığ 1 ortam sayesinde e-WOMM'da veri ve yorumların toplanabilmesi imkânı vardır.

- e-WOMM'da ağızdan ağıza pazarlamada olduğu gibi yorum ağırlıklı aktarımlardan başka ürün/hizmet vb. hakkında iş ve kullanım bilgileri de takas edilmekte ve derlenebilmektedir.

- e-WOMM, belirli bir ortamda (internet) ilgili yazıl1/kayıtlı ifadelerin bulunmasıyla birlikte bir birikimsellik taşımakta ve bir arşiv ortamı oluşturmaktadır. Bu da onun ölçümlenebilmesini kolaylaştıran bir unsurdur.

- İnternet kullanımının tüm dünyada yaygınlaşmasıyla e-WOMM insanların davranışlarında değişikliklere neden olmaktadır. Günümüzde tüketiciler hangi filmi izleyeceklerinden hangi restoranda yiyeceklerine, hangi marka ayakkabıyı giyeceklerine 
Ağıdan Ağıza Pazarlama Tekniklerinin Marka Tercihine Etkisi

kadar kararlarını internetteki diğer tüketicilerin tecrübelerinden yararlanarak almaktadırlar. Ağızdan ağıza pazarlamada amaç, tüketicileri kampanyanın bir parçası haline getirerek, onları bir marka elçisine dönüştürerek, kuruluşun satış elemanı gibi davranmalarını sağlamaktır. Hedef, tüketiciye bir mesaj iletmekten ziyade, tüketicilerle birlikte bir mesaj yaratmaktır.

Pazarlama literatüründe ağızdan ağıza pazarlama diğer pazarlama iletişimi unsurlarıla birlikte değerlendirilmekte ve diğer pazarlama çabalarıyla yakın ilişki içerisinde ele alınmaktadır. Ağızdan ağıza pazarlama kampanyası tek başına yürütülürse arzu edilen sonucun elde edilmesi mümkün olmaz. ${ }^{15}$ Reklam, halkla ilişkiler, doğrudan pazarlama gibi diğer pazarlama iletişimi unsurlarıyla desteklenmelidir.

Stauss, tüketicilerin çevrimiçi yorumlarındaki artışın kurumlar için firsatlar yarattığı kadar tehditler de oluşturduğunu belirtmektedir. Tüketiciler internet ortamında ürünler, markalar, kurumlarla yaşadıkları olumlu ya da olumsuz tecrübelerini diğer tüketicilerle paylaşırken ağızdan ağıza iletişimi kullanırlar. ${ }^{16}$

Anderson gibi bazı yazarlar ağızdan ağıza iletişimin, özellikle bu tecrübelerin tatmin ediciliği olmadığı durumlarda arttığını savunmaktadır. Kızgınlık insanları konuşturan duygulardandır. Tüketiciler olumsuz tecrübelerini paylaşırken aynı zamanda öfkelerini de paylaşıyor, gerginliklerini azaltıyor, kendi yaşadıkları sorunları başkalarının da yaşamasına engel oluyor, sorunları çözme konusunda da tavsiye alıyorlar. İnsanlar yaşadıkları olumsuz deneyimleri, kızgınlıklarını diğer insanlarla paylaşarak bu duygularını hafifletmek, diğer insanları da aynı olayla karşılaşmamaları için uyarmak isterler. Tüketicilerin olumsuz deneyimlerini paylaşımlarına kurumların engel olması mümkün değildir. Ancak kurumlar, tüketicilerin olumsuz deneyimleri sonrasında yaşayacakları süreci doğru yönetebilirlerse, krizleri firsata dönüştürebilirler. Önemli olan tüketicilerin

\footnotetext{
${ }^{15}$ D.Ahuja vd., "Teen Perceptions of Disclosure in Buzz Marketing”, Journal of Consumer Marketing, 2007, 24 (3), 151-159, s.151.

${ }^{16}$ Bernd Stauss, Using New Media for Costumer Interaction: A Challenge for Relationship Marketing, (Berlin, In T. Henning-Thurau \& U.Hansen 2000), 233-253, s.233.
} 


\section{Nihal TOROS DAPIAPIS}

yaşadıkları olumsuzluklar, kızgınlıklar, hayal kırıklıkları sonrasında onların fikirlerini değiştirebilecek stratejiler geliştirebilmektir.

Dichter, Engel, Blackwell, Miniard, Sundaram, Mitra, Webster gibi yazarlar tatmin edici tecrübelerin paylaşılmasının, olumsuz tecrübelerin paylaşılmasından farklı nedenlerle gerçekleştiğini savunmaktadırlar. Dichter'e göre, ${ }^{17}$ olumlu ağızdan ağıza yayılma (WOM - Word of mouth) iletişiminin temelinde tüketicinin ürüne karşı duyduğu yüksek orandaki bağlılık, ürün için bir şeyler yapması konusunda baskıya neden olur; ayrıca tüketici bu yolla bir takım duygusal ihtiyaçlarını da doyurabilir. Engel, Blackwell ve Miniard'a göre ${ }^{18}$ ise, konuya olan ilgi tüketiciyi tartışma ortamına girmeye teşvik eder, tavsiyeler ilgisini çeker, ürün/kurum/marka ile ilgili tecrübelerini paylaşırken içeriden bilgi veriyormuş gibi hisseder ve çevresindekilere satın alma kararı aşamasında yardımcı olmaktan mutluluk

Üsküdar University Journal of Social Sciences Year:1 Issue:1 duyar. Ayrıca çeşitli reklamlar ve satış promosyonları hakkına konuşurken eğlenir, satın alma sonrasındaki kuşkularını giderir. Mutluluk, insanların konuşma ve duygularını paylaşma nedenlerden bir tanesidir. İnsanlar mutlu olduklarında hissettikleri bu duyguyu arkadaşlarıyla, aile bireyleriyle paylaşmak isterler. Sundaram, Mitra, Webster'e göre ${ }^{19}$ de ağızdan ağıza iletişimde bulunulmasının temelinde sonucunda bir ödül beklemeden başkaları için bir şeyler yapma isteği, ürüne olan kişisel ilgi, ürüne sahip olmaktan kaynaklanan heyecan, diğer tüketicilerin gözünde akıllı tüketici olma arzusu, kendini tatmin eden kuruma destek olmak gibi nedenler yatmaktadır. Bu durum, pazarlama uzmanlarının pazara sundukları ürün ya da hizmetin tüketiciler tarafindan sevilmesinin ve onları mutlu etmesinin ne kadar önemli olduğunu göstermektedir.

Ağızdan ağıza iletişimde; negatif ağızdan ağıza iletişimin, pozitif ağızdan ağıza iletişimden daha hızlı bir şekilde yayıldığı kabul edilmektedir. Ağızdan ağıza iletişim, tatmin gerçekleştiremeyen firmaların ürünlerinin

\footnotetext{
${ }^{17}$ Ernest Dichter, "How Word-of-Mouth Advertising Works", Harvard Business Review 44, 1966, 147 166, s.154.

${ }^{18}$ J.F. Engel vd., Consumer Behavior, 5th Ed., (New York: Dryden Press 1993), s.46.

19 D.S. Sundaram vd., "Word-of-Mouth Communications: A Motivational Analysis in Consumer Research", 25(1), (USA: 1998), 527-531, s.529.
} 
tercih edilmemesine hatta piyasadan yok olmasina neden olabilir. ${ }^{20} \mathrm{Bu}$ durum, ağızdan ağıza iletişimin; ürünlerin, markaların, hatta kurumların yok olmasına neden olabilecek kadar güçlü olduğunu ortaya koymaktadır.

Hazır giyim sektörüne baktığımızda sektörde her geçen gün ulusal ve uluslararası yeni firmaların yer aldığı görülmektedir. Bu ortamda rekabet artmakta, tüketicinin markalar arasında seçimi zorlaşmaktadır. Tüketici için, marka olan ürünleri tüketmenin hazzını yaşarken diğer taraftan çevresi tarafından beğenilmek de önem taşımaktadır.

\section{Metodoloji}

Anket çalışması; tüketicilerin dış giyim ürünü satın alma kararlarını neye göre verdiklerini, marka tercihlerinde diğer tüketicilerin tavsiyelerinden etkilenip etkilenmediklerini, dijital ortamda ağızdan ağıza pazarlama faaliyetinde bulunup bulunmadıklarını demografik değişkenler göz önünde bulundurularak ölçmek amaciyla gerçekleştirilmiştir.

Araştırma evreni, çok geniş olması nedeniyle İstanbul ili ile sınırlandırılmıştır. İstanbul il nüfusu dikkate alındığında ana kütlenin büyüklüğü nedeniyle, dış giyim ürünü satın alan tüm tüketicilere ulaşmak imkânsızdır. Zaman ve maliyet kısıtlamaları da göz önüne alınarak anket çalışması, İstinye Park, Ataköy A Plus, Güngören Kale, Zeytinburnu Olivium Alışveriş Merkezleri ile sınırlandırılmıştır.

Araştırma yüz yüze anket tekniği kullanılarak gerçekleştirilmiştir. Daha bağımlı değişken kabul edilen değişkenler karşısında, çeşitli demografik değişkenlerin ilişkileri ölçülmüştür.

Çalışmanın ana konusu, tüketicilerin dış giyim marka tercihlerinde, diğer tüketicilerin yorumlarının önemini ortaya koymaktır. Bu doğrultuda Türkiye'de dış giyim satın alan tüketiciler, yani tüm halk araştırmanın evrenini oluşturmaktadır. Evrenin bu derece geniş olması, zaman ve maliyet

${ }^{20}$ M. Argan, M.T. Argan, "Viral Pazarlama veya İnternet Üzerinde Ağızdan Ağıza Reklam: Kuramsal Bir Çerçeve”, Sosyal Bilimler Dergisi, 2006, 231-250, s. 234. 


\section{Nihal TOROS DAPIAPIS}

açısından kısıtlamaları da beraberinde getirmektedir. Bu nedenle, evrenden örneklem seçimi yoluna gidilmiştir. Çalışmanın örneklemi seçilirken İstanbul ili baz alınmıştır. Araştırma, adı geçen alışveriş merkezlerinde çeşitli markalara ait dış giyim ürünleri satın alan toplam 300 tüketici üzerinde gerçekleştirilmiştir.

Anket formunun geliştirilmesi, marka tercihinde ağızdan ağza pazarlamanın etkililiğini ölçmeye yardımcı olacak sorular kullanılarak gerçekleştirilmiştir. İlk iki soru, katılımcıların demografik özelliklerine ilişkindir. Daha sonraki sorularda reklamın marka tercihindeki etkisi değerlendirilmiş, tüketicilerin dijital ortamda ağızdan ağıza pazarlamaya dâhil olup olmadıkları, olumsuz tavsiyelerin tüketiciyi etkileyip etkilemediği, tavsiye sonucu gerçekleştirilen satın alma eylemlerinde en güvenilir kaynağın ortaya konulması amaçlanmış ve tüketicilerin dijital ortamda marka tercihlerine ilişsin bilgi yayıp yaymadıkları araştırılmıştır.

Usküidar

Journal of

Veriler SPSS 17.0 programında değerlendirilmiştir. Değişkenler arası ilişkilerin belirlenmesinde 1 Örneklemli T Testi'nden (1 Sample T Test) yararlanılmıştır. Ayrıca çalışmada bazı sorular için karşılaştırmalı tablolar (crosstabs) kullanılarak anlamlı ilişkilerin dile getirilmesi amaçlanmıştır.

\section{Bulgular}

Araştırma örneklemini oluşturan kitle eşit olarak kadın ve erkek bireyler arasından seçilmiştir. Örneklemin demografik verilerini oluşturan etkenlerden biri olarak da kitle 18 yaş ve altı, 19-29, 30-39, 40-49 ve 50 yaş üzeri olarak \%20'şerlik eşit gruplar halinde seçilmiştir. Eğitim seviyesinde \%30,6 ile ağırlığı lisans mezunları oluştururken en küçük grubu \%9,6 ile yüksek lisans ve doktora eğitimi almışlar oluşturmaktadır (Bkz. Tablo: 1). 
Ağızdan Ağıza Pazarlama Tekniklerinin Marka Tercihine Etkisi

Tablo: 1 Katılımcıların Demografik Özellikleri

\section{Cinsiyet}

Kadın

150

50

Erkek

150

50

Yaș Grubu

18 ve altı

60

20

19-29

60

20

30-39

60

20

40-49

60

20

50 ve üzeri

60

20

Eğitim Seviyesi

İlköğretim

65

21,6

Lise

79

26,3

Önlisans

35

11,6

Lisans

92

30,6

Yüksek Lisans/Doktora

29

9,6 


\title{
Nihal TOROS DAPIAPIS
}

Katılımcıların dış giyim markası tercih etme kararlarını etkileyen en geçerli yöntem, markanın çevrede moda olmasıdır. Bu yöntemi sırasıyla tanınmış kişiler ve sanatçıların tavsiyesi, yakınların ve arkadaşların tavsiyesi, bloglarda yazılan marka ile ilgili yorumlar, üreticinin kendi web sitesinde marka ile ilgili söyledikleri, markanın tv, dergi ya da gazete reklamları, radyo reklamları ve üreticinin marka için hazırlamış olduğu bilgisayar oyunu izlemektedir (Bkz. Tablo: 2).

\section{Tablo: 2 Tüketicilerin Dış Giyim Markası Tercih Etme Kararlarını Etkileyen Yöntemler}

\begin{abstract}
Aşağıdakilerden hangisi bir dış giyim markasını satın alma kararınızı etkileyen en geçerli yöntemdir? Önem sırasına göre 1'den 9'a kadar numaralandırınız. ( $1=$ en çok etkileyen, $9=$ en az etkileyen)
\end{abstract}

\begin{tabular}{lcc|}
\hline & Frekans & Sıralama \\
\hline $\begin{array}{l}\text { Yakınlarınızın ya da arkadaşlarınızın } \\
\text { tavsiyesi }\end{array}$ & 4,92 & 3 \\
\hline $\begin{array}{l}\text { Bloglarda yazılan marka ile ilgili } \\
\text { yorumlar }\end{array}$ & 4,96 & 4 \\
\hline $\begin{array}{l}\text { Üreticinin marka için yapmış olduğu } \\
\text { bilgisayar oyunu }\end{array}$ & 7,77 & 9 \\
\hline Üreticinin web sitesi & 5,11 & 5 \\
\hline $\begin{array}{l}\text { Markanın çevrenizde moda olması } \\
\text { Tanınmış kişiler ve sanatçıların }\end{array}$ & 1,47 & 1 \\
\hline tavsiyesi & 2,04 & 2 \\
\hline Markanın Tv reklamı & 5,17 & 6 \\
\hline Markanın basılı medya reklamları & 5,94 & 7 \\
\hline Markanın radyo reklamları & 7,59 & 8
\end{tabular}


Ağıdan Ağıza Pazarlama Tekniklerinin Marka Tercihine Etkisi

Tablo: 3'de görüldüğü üzere katılımcıların \%1,3'ü reklama çok inandıklarını, \%16,7'si inandıklarını, \%54'ü ne inanıp ne inanmadıklarını, $\% 25,7$ 'si inanmadıklarını, \%2,3'ü ise hiç inanmadıklarını belirtmişlerdir. $\mathrm{Bu}$ durumda reklama inanmayanların ve hiç inanmayanların oranı \%28 iken, inananların ve çok inananların oranı sadece \%18'dir.

\section{Tablo: 3 Reklamlara Duyulan Güven}

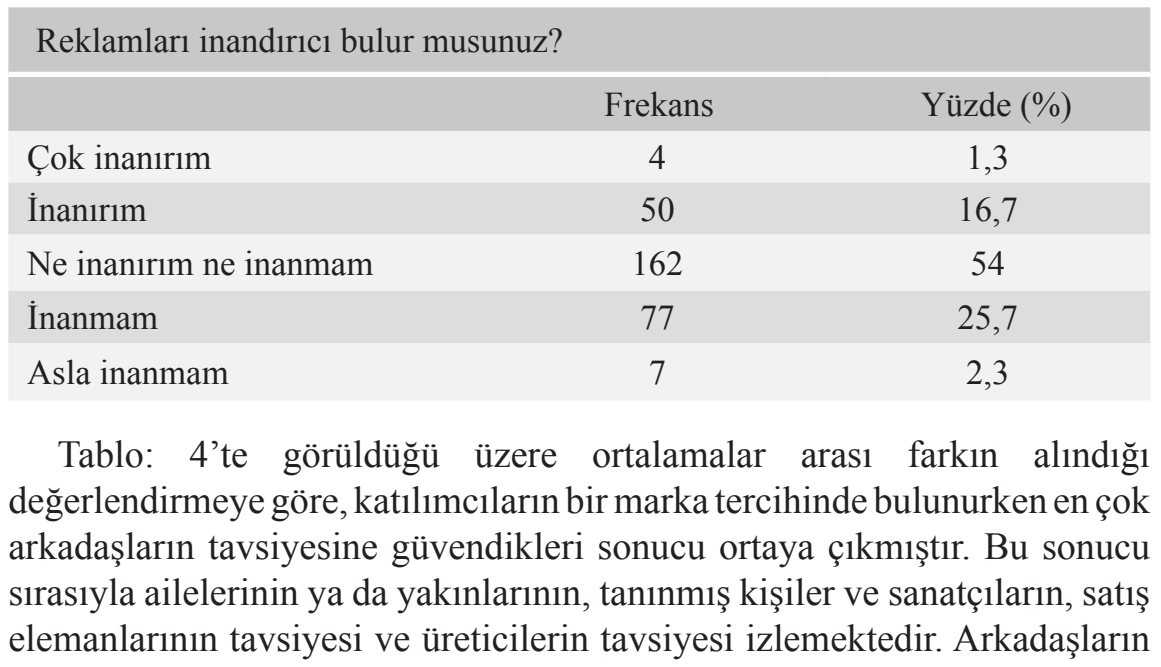




\section{Nihal TOROS DAPIAPIS}

tavsiyesinin ilk sırada yer almasının, dış giyimin moda ve sosyal çevrede kabullenmeyle olan ilişkisinden kaynaklandığı düşünülmektedir.

\section{Tablo: 4 Tavsiyesine En Güvenilen Kişiler}

Bir marka tercihinde bulunurken en çok aşağıdakilerden hangisinin tavsiyesine güvenirsiniz? Önem sırasına göre 1'den 5'e kadar numaralandırınız. (1=en çok güvenilen, 5=en az güvenilen)

Üsküdar University Journal of Social Sciences

Year:1

Issue:1

\section{Frekans}

Siralama

$\begin{array}{lc}\text { Arkadaşların tavsiyesi } & 1,33 \\ \text { Tanınmış kişiler ve } & 3,92 \\ \text { sanatçıların tavsiyesi } & 3,99 \\ \text { Üreticilerin tavsiyesi } & 3\end{array}$

Satış elemanlarının tavsiyesi

3,94

Katılımcıların \%13,3'ü marka tercihinde bulunurken başkalarından duydukları olumlu değerlendirmelerin satın alma kararlarında çok etkili olduğunu söylerken, \%80,7'si etkili olduğunu, sadece \%0,7'si etkili olmadığını ve yine $\% 0,7$ 'si hiç etkili olmadığını belirtmiştir. Ne etkilidir, ne etkili değildir yanıtını verenlerin oranı ise \%4,7'dir (Bkz. Tablo: 5).

\section{Tablo: 5 Tavsiyenin Tüketicilerin Dış Giyim Marka Tercihi} Üzerindeki Etkisi

Dış giyim marka tercihinizde, diğer tüketicilerin tavsiyesi etkili midir?

\begin{tabular}{|lcc|} 
& Frekans & Yüzde (\%) \\
\hline Çok etkilidir & 40 & 13,3 \\
\hline Etkilidir & 242 & 80,7 \\
Ne etkilidir ne etkili değildir & 14 & 4,7 \\
\hline Etkili değildir & 2 & 0,7 \\
\hline Hiç etkili değildir & 2 & 0,7
\end{tabular}


Ağızan Ağıza Pazarlama Tekniklerinin Marka Tercihine Etkisi

Katılımcıların \%23'ü herhangi bir dış giyim ürünü satın alırken marka tercihinde, başkalarından duydukları olumsuz yorumların satın alma kararlarında çok etkili olduğunu söylerken, \%69'u etkili olduğunu, sadece $\% 2,3$ 'ü etkili olmadığını ve yine \%0,3'ü hiç etkili olmadığını belirtmiştir. Ne etkilidir, ne etkili değildir yanıtını verenlerin oranı ise \%4,7'dir (Bkz. Tablo: 6).

\section{Tablo: 6 Olumsuz Yorumların Tüketicilerin Marka Tercihi Üzerindeki Etkisi}

Diğer tüketicilerin herhangi bir markayla ilgili olumsuz değerlendirmeleri/ şikâyetleri, markayı tercih etmekten vazgeçmenizde etkili midir?

\begin{tabular}{|lcc|} 
& Frekans & Yüzde (\%) \\
\hline Çok etkilidir & 71 & 23 \\
Etkilidir & 207 & 69 \\
Ne etkilidir ne etkili değildir & 14 & 4,7 \\
Etkili değildir & 7 & 2,3 \\
\hline Hiç etkili değildir & 1 & 0,3
\end{tabular}

Ortalamalar arası farkın alındığı değerlendirmeye göre, katılımcıların beğendikleri bir markayı bir başkasına tavsiye ederken en çok kullandıkları iletişim yönteminin yüz yüze konuşmak olduğu sonucu ortaya çıkmıştır. Yüz yüze konuşmayı; sosyal paylaşım ağlarında paylaşmak, telefonda konuşmak, ürün ile ilgili yorumları bloglarda yazarak diğer internet kullanıcılarıyla paylaşmak ve tanıdıklarına e-posta göndermek seçenekleri izlemektedir (Bkz. Tablo: 7). Bu sonuçlar bize yüz yüze iletişimin önemli bir tavsiye aracı olduğunu gösterirken sosyal paylaşım ağlarında paylaşımın ikinci sırada yer alması, sosyal paylaşım ağlarının giderek önemli bir tavsiye aracı haline geldiğine işaret etmektedir. 


\section{Nihal TOROS DAPIAPIS}

\section{Tablo: 7 Bir Dış Giyim Markası Tavsiye Ederken Kullanılan İletişim Yöntemleri}

Üsküdar University Journal of Social Sciences Year:1 Issue:1

Beğendiğiniz bir markayı bir başkasına tavsiye ederken hangi iletişim yöntemini kullanırsınız? Önem sırasına göre 1'den 5'e kadar numaralandırınız. ( $1=$ en çok kullanılan, $5=$ en az kullanılan)

\begin{tabular}{|lcc|}
\hline & Frekans & Siralama \\
\hline Yüz yüze konuşmak & 1,08 & 1 \\
\hline Telefonda konuşmak & 3,32 & 3 \\
\hline Sosyal paylaşım ağlarında paylaşmak & 2,65 & 2 \\
\hline Tanıdıklarınıza e-posta göndermek & 4,52 & 5 \\
$\begin{array}{l}\text { Ürün ile ilgili yorumunuzu bloglarda } \\
\text { yazarak internet kullanıcılarıyla } \\
\text { paylaşmak }\end{array}$ & 3,40 & 6
\end{tabular}

Tüketici kaynaklı içeriklerin hazırlanması ve dağıtılması ile ilgili soruya yanıt veren katılımcıların \%23'ü herhangi bir ürün, konu ya da marka ile ilgili yazı ya da görsel oluşturup, bunları internet ortamında diğer tüketicilerle sık sık paylaştığını, \%69'u bazen paylaştığını, \%4,7'si ise bugüne kadar hiç paylaşmadığını belirtmiştir (Bkz. Tablo: 8). Youtube, Wikipedia, Bloglar vb. tüketici kaynaklı medyada içerik oluşturmanın katılımcılar arasında çok popüler olmadığ görülmektedir 
Ağızan Ağıza Pazarlama Tekniklerinin Marka Tercihine Etkisi

\section{Tablo: 8 Tüketici Kaynaklı Medya İçeriklerinin Oluşturulması}

Herhangi bir ürün, konu ya da marka hakkında yazı ya da görsel oluşturup, bunu internet ortamında diğer tüketicilerle paylaştınız mı? (Youtube, bloglar, Wikipedia vb.)

\begin{tabular}{lcc|} 
& Frekans & Yüzde (\%) \\
\hline Sık sık & 22 & 7,3 \\
Bazen & 85 & 28,3 \\
Hiçbir zaman & 193 & 64,3
\end{tabular}

150 kadın katılımcının vermiş olduğu yanıtlara göre, satın alma kararlarını etkileyen yöntemlerin önem sırası şu şekildedir: Markanın moda olması, tanınmış kişiler ya da sanatçıların tavsiyesi, yakınlarının ya da arkadaşlarının tavsiyesi, ürünün televizyondaki reklamı, bloglarda marka ile ilgili yazılan yorumlar, üreticinin web sitesi, dergi ya da gazete reklamları, radyo reklamları, üreticinin marka için hazırlamış olduğu bilgisayar oyunu (Bkz. Tablo: 9). Sonuçlar, modanın kadınlar açısından doğal bir tavsiye aracı olduğunu göstermektedir.

150 erkek katılımcının yanıtları ise şu şekilde sıralanmaktadır: Yakınlarının ya da arkadaşlarının tavsiyesi, markanın moda olması, bloglarda yazılan marka ile ilgili yorumlar, üreticinin web sitesi, tanınmış kişiler ya da sanatçıların tavsiyesi, ürünün televizyondaki reklamı, dergi ya da gazete reklamları, üreticinin ürün için yapmış olduğu bilgisayar oyunu ve radyo reklamları (Bkz. Tablo: 9). Sonuçlarda, erkekler için en önemli tavsiye aracının yakınlar ve arkadaşlarının tavsiyesi olurken, modanın onun ardından gelmesi dikkat çekicidir. 


\section{Nihal TOROS DAPIAPIS}

\section{Tablo: 9 Tüketicilerin Kozmetik Ürünü Satın Alma Kararlarını Etkileyen Yöntemler ve Cinsiyet İlişkisi}

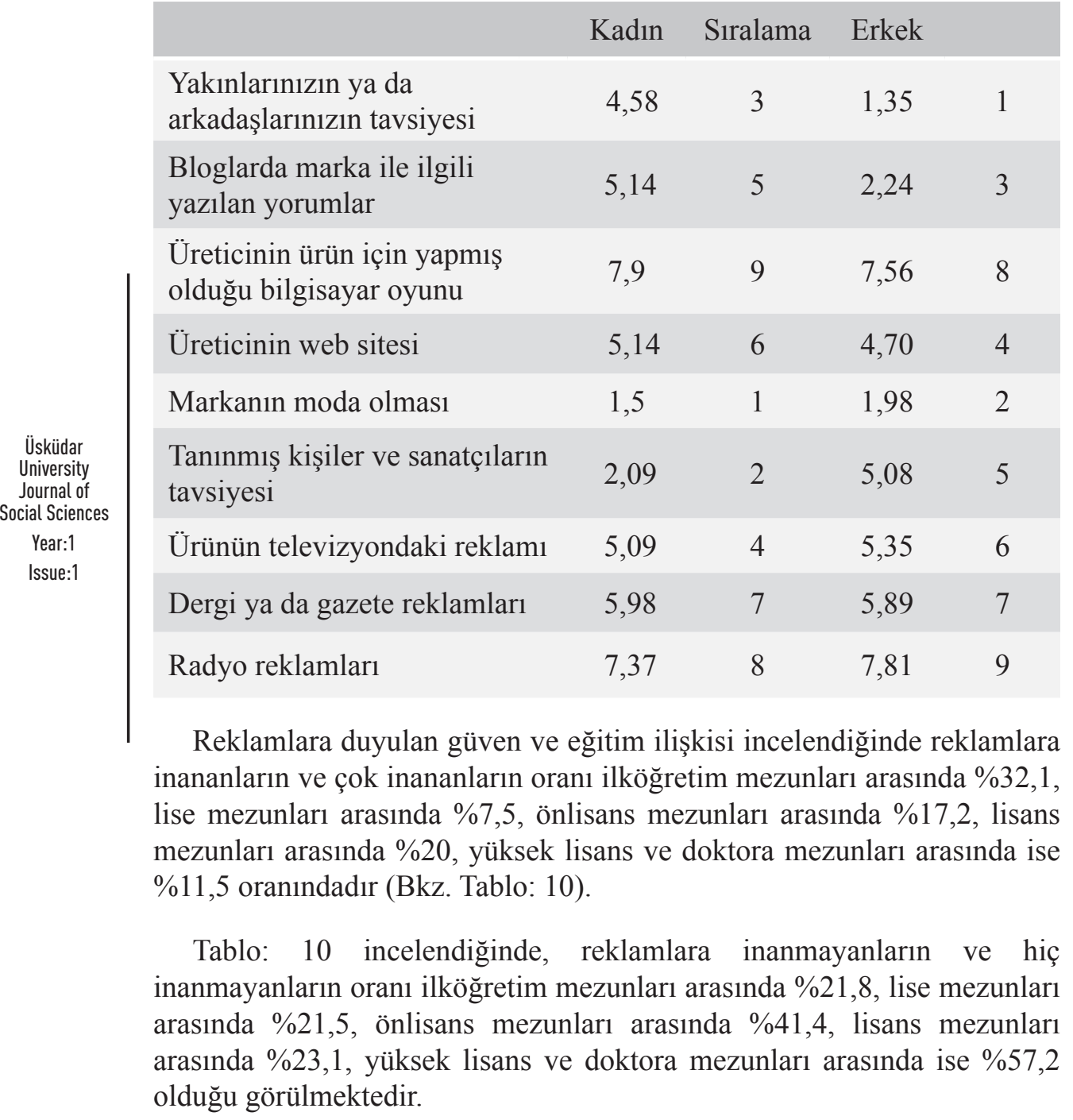


Ağızan Ağıza Pazarlama Tekniklerinin Marka Tercihine Etkisi

"Ne inanıyorum ne inanmiyorum" yanitını veren katılımcların oranı ilkokul mezunları arasında $\% 46,2$, lise mezunları arasında \%71, önlisans mezunları arasında $\% 41,4$, lise mezunları arasında $\% 56,9$, yüksek lisans/ doktora mezunları arasında ise \%31,4'tür (Bkz. Tablo: 10).

Tablo: 10 Reklamlara Duyulan Güven ve Eğitim İlişkisi

\begin{tabular}{lccccc} 
& $\begin{array}{c}\text { İlköğretim } \\
(\%)\end{array}$ & $\begin{array}{c}\text { Lise } \\
(\%)\end{array}$ & $\begin{array}{c}\text { Önlisans } \\
(\%)\end{array}$ & $\begin{array}{c}\text { Lisans } \\
(\%)\end{array}$ & $\begin{array}{c}\text { Y.Lisans/ } \\
\text { Doktora } \\
(\%)\end{array}$ \\
\hline Çok inanıorum & 0 & 0 & 6,9 & 1,5 & 2,9 \\
\hline İnanıyorum & 32,1 & 7,5 & 10,3 & 18,5 & 8,6 \\
\hline $\begin{array}{l}\text { Ne inaniyorum } \\
\text { ne inanmiyorum }\end{array}$ & 46,2 & 71 & 41,4 & 56,9 & 31,4 \\
$\begin{array}{l}\text { İnanmiyorum } \\
\text { Hiç }\end{array}$ & 19,2 & 21,5 & 41,4 & 20 & 48,6 \\
inanmiyorum & 2,6 & 0 & 0 & 3,1 & 8,6
\end{tabular}

18 yaş ve altı katılımcıların 90'1, 19-29 yaş arasındakilerin \%91,7'si, 30-39 yaş arasındakilerin \%95'i, 40-49 yaş arasındakilerin \%096,7'si, 50 yaş ve üzerindekilerin ise \%96,6's1 tavsiyenin "çok etkili ve etkili" olduğunu söylemiştir. 18 yaş ve altı, 40-49 yaş arası katılımcılardan "etkili değildir ya da hiç etkili değildir" yanıtını veren katılımcıya rastlanmamıştır. 19-29 yaş arası katılımcılardan sadece \%3,4'ü "etkili değildir ve hiç etkili değildir" yanıtını vermişken, bu oran 30-39 yaş arası, 50 yaş ve üzeri katılımcılarda \%1.7'ye düşmektedir (Bkz. Tablo: 11). 


\section{Nihal TOROS DAPIAPIS}

\section{Tablo: 11 Tavsiyenin Dış Giyim Markası Tercihi Üzerindeki Etkisi ve Yaş İlişkisi}

\begin{tabular}{|c|c|c|c|c|c|c|}
\hline & & $\begin{array}{l}18 \text { ve altı } \\
(\%)\end{array}$ & $\begin{array}{c}19-29 \\
(\%)\end{array}$ & $\begin{array}{c}30-39 \\
(\%)\end{array}$ & $\begin{array}{c}40-49 \\
(\%)\end{array}$ & $\begin{array}{l}50+ \\
(\%)\end{array}$ \\
\hline & Çok etkilidir & 15 & 10 & 18,3 & 10 & 13,3 \\
\hline & Etkilidir & 75 & 81,7 & 76,7 & 86,7 & 83,3 \\
\hline & $\begin{array}{l}\text { Ne etkilidir ne etkili } \\
\text { değildir }\end{array}$ & 10 & 6 & 3,3 & 3,3 & 1,7 \\
\hline & Etkili değildir & 0 & 1,7 & 1,7 & 0 & 0 \\
\hline & Hiç etkili değildir & 0 & 1,7 & 0 & 0 & 1,7 \\
\hline $\begin{array}{c}\text { Üskiüdar } \\
\text { University } \\
\text { Journal of } \\
\text { Social Sciences } \\
\text { Year:1 } \\
\text { Issue:1 }\end{array}$ & \multicolumn{6}{|c|}{$\begin{array}{l}\text { Hazır giyim sektöründe marka tercihinde reklam, PR, indirimler, } \\
\text { promosyonlar, ürüne sahip olmaktan duyulan haz gibi birçok faktörün } \\
\text { etkisi olduğu kuşkusuzdur. Ancak günümüzde oldukça yaygın kullanılan } \\
\text { e-WOMM'ın da etkisi yadsınamaz. e-WOMM aracıllğıyla markalar } \\
\text { tüketicileriyle yakın bağ kurabildikleri gibi ürünleriyle ilgiliolumsuzlukların } \\
\text { da bu yolla kısa süre içinde yayılması kaçınılmazdır. Markalar yeni sezon } \\
\text { ürünlerini, kataloglarını, indirimleri, özel promosyonlarıyla ilgili bilgileri } \\
\text { müşterilerine e-mail, sms, mms, web siteleri gibi yollarla iletebildikleri gibi, } \\
\text { müşterileriyle interaktif iletişim kurma olanağına da sahip olabilmektedirler. } \\
\text { Öte yandan Markafoni, Trendyol gibi online alışveriş siteleri de bir çok } \\
\text { marka ve ürünü pazarlarken online alışveriş yapan müşterilere ulaşabilmekte } \\
\text { ve e-WOMM'1 etkin olarak kullanmaktadırlar. }\end{array}$} \\
\hline & $\begin{array}{l}\text { D1ş giyim sektörü } \\
\text { oda doğal bir tavsi } \\
\text { ğları ve dijitial med }\end{array}$ & $\begin{array}{r}\text { odaya ç } \\
\text { arac1 g }\end{array}$ & ağ 11 & Ir sel & olma & $\begin{array}{l}\text { yısıyla } \\
\text { ylașim }\end{array}$ \\
\hline
\end{tabular}


mümkündür. Günümüzde sosyal paylaşım ağları önemli tavsiye aracı olma görevini üstlenmekte ve gündemi belirlemektedir.

Bloglar, tartışma platformları gibi ortamlar; müşterilerin satın aldıkları markalarla ilgili olumlu ya da olumsuz tecrübelerini paylaştıkları ortamlar olduklarından, ürünle ilgili yıpranma, solma, deforme olma, sökülme, çekme, yırtılma vb. sorunların paylaşıldığı ve tartışıldığı ortamlardır. Özellikle tüketici firmaya ürünle ilgili bir şikâyetle gidip de olumsuz cevapla döndüğünde, diğer insanlarla bu olumsuz tecrübesini paylaşarak bir şekilde firmayla hesaplaşır. Sosyal medyada tweet atar, tüm takipçileri x marka t-shirt'ün ilk yıkamada solduğunu öğrenir; Facebook'ta duvarına yazar, yüzlerce arkadaşı öğrenir, yazdıklarını beğenen arkadaşlarının yüzlerce arkadaşı da görür, böylece tıpkı bir virüs gibi markayla ilgili yaşadığı tecrübe yayılır.

Marka tercihi bireylerin sosyal yaşamdaki statülerini belirleyen bir unsurdur. Kullandığımız markalar bizim kim olduğumuzun aynasıdır. Özellikle toplumca tanınmış ünlü kişilerin kullandığı markalar, onlara hayran olan, onlara özenen, onun gibi olma isteği olan kişilerin satın alma davranışı üzerinde kuşkusuz etkili olur. Bu kişilerin geleneksel medyada olduğu kadar dijital medyada yer alan fotoğrafları ya da tercih ettikleri ürünlerle ilgili yorumları tüketici tercihleri üzerinde etkilidir.

Firmalar değişen çağa ayak uydurabilmek ve her geçen gün artan ulusal ve uluslararası rekabete rağmen tercih edilir olabilmek için tavsiyeden yararlanmak zorundadırlar. Tüketicilerin dost, arkadaş, akraba tavsiyelerinin dijital çağda dijital ortamdan geçtiği unutulmamalıdır. Pazarlama iletişimi çabalarında dijital ortamdan yararlanılmalıdır. Firmalar sms, mms, e-mail, e-kataloglar, sosyal paylaşım ağları, bloglar gibi yollarla tüketicilerini yeni sezon ürünleri, indirimler, promosyonlar hakkında bilgilendirirken marka olmanın ön koşulu olan farklılaşmayı, özel olmayı da gözden kaçırmamalıdırlar. Çünkü tüketicilere her gün onlarca online pazarlama enformasyonu gelmektedir. Bunların arasından ancak fark edilir olabilirseniz tüketiciye ulaşma imkânınız olabilir. 


\section{Nihal TOROS DAPIAPIS}

Özellikle genç tüketicilere hitap eden markaların reklam advergameleri kullanmaları, bu oyunların içinde sezon ürünlerinin ve markalarının görünmesini sağlamaları müşterilerine ulaşmalarının etkili bir yoludur; reklam olduğu hissettirilmeden tüketici algısına ulaşmanın ve zihninde yer etmenin, olumlu bir tecrübe yaşatmanın yöntemidir.

Firmalar, kendileri de, tartışma platformları, bloglar kurarak tüketicilerin ürün hakkında konuşmalarını sağlamalı, düzenli olarak bu platformları takip ederek, müşterilerinin nabzını tutmalıdır. Bu yolla firmaların memnuniyetsiz müşterileri fark etmeleri, memnuniyetsizliklerini gidermeleri ve tercih edilir marka haline gelmeleri mümkün olabilir.

Üsküdar University Journal of Social Sciences

Year:1

Issue:1

\section{KAYNAKCุA}

Amy Dusto, "43 \% more Europeans shop via mobile this year", 24 Ekim 2013, Erişim 5 Mart 2015, https://www.internetretailer.com/2013/10/24/43-more-europeans-shopmobile-year

Bernd Stauss, Using New Media for Costumer Interaction: A Challenge for Relationship Marketing, (Berlin: In T. Henning-Thurau \& U.Hansen 2000), 233-253.

D. Ahuja, T.A. Roshan, M.M. Michels, M.Walker, \& M. Weissbuch, "Teen Perceptions of Disclosure in Buzz Marketing", Journal of Consumer Marketing, 2007, 24 (3), 151-159.

D.S. Sundaram, K. Mitra \& C. Webster, "Word-of-Mouth Communications: A Motivational Analysis in Consumer Research", 25(1), (USA: 1998), 527531.

Ernest Dichter, "How Word-of-Mouth Advertising Works", Harvard Business Review 44, 1966, 147-166. 
Ağızdan Ağıza Pazarlama Tekniklerinin Marka Tercihine Etkisi

Filiz Balta Peltekoğlu, Halkla İlişkiler Nedir?, 5. Bask1, (İstanbul: Beta Basım A.Ş. 2007).

Hilmi Öğütçü, "2009 - 2013 Yılları Arası Türkiye E Ticaret Büyüme Oranı ve Hacmi”, 18 Mayıs 2014, Erişim 12 Şubat 2015, http://www.egirisim.com/2009-2013-yillari-arasi-turkiye-e-ticaretbuyume-orani-ve-hacmi/

Internet ve mobil Pazar istatistikleri-2013 Q2 Türkiye Raporu, 20 Eylül 2013, Erişim 5 Mart 2015,

http://www.connectedvivaki.com/turkiyede-internet-ve-mobil-pazaristatistikleri-btk-2013-q2-raporu

İzzet Bozkurt, İletişim Odaklı Pazarlama, (İstanbul: Media Cat 2004).

J.F. Engel, R.D. Blackwell \& P.W. Miniard, Consumer Behavior, 5th Ed., (New York: Dryden Press 1993).

Justin Kirby, Online Viral Marketing: The Strategic Synthesis In Peerto-Peer Brand Marketing, Brand Channel White Paper, (Digital Media Communications Ltd. 2004).

"Kalkınma Bakanlığ internet girişimciliği ve e-ticaret raporu yayınladı", E-Ticaret Mag, 6 Şubat 2013, Erişim 2 Mart 2015, http://eticaretmag.com/kalkinma-bakanligi-internet-girisimciligi-ve-eticaret-raporu-yayinladi/

"Master Index, (2011) Aralık 2011 Araştırma Sonuçları", 16 Nisan 2012, Erişim 25 Mart 2013, http://www.mastercard. com/tr/personal/tr/promotions/ MasterIndexARALIK2011Banka.pdf

M. Argan, M.T. Argan, "Viral Pazarlama veya İnternet Üzerinde Ağızdan Ağıza Reklam: Kuramsal Bir Çerçeve”, Sosyal Bilimler Dergisi, 2006, 231-250. 


\section{Nihal TOROS DAPIAPIS}

Selma Özçoban, "Türk Hazır giyim Ürünlerinin Pazarlarda Yer Almasında Marka İmajı Yaratmanın Önemi ve Sarar giyim A.Ş. ye ait Uygulama”, Anadolu Üniversitesi Sosyal Bilimler enstitüsü, Basılmamış Yüksek Lisans Tezi, 2003, Eskişehir.

T.C. Kalkınma Bakanlığı, Bilgi Toplumu Stratejisinin Yenilenmesi Projesi, Internet Girişimciliği ve e-Ticaret Ekseni Mevcut Durum Raporu, 10 Nisan 2013.

“Türkiye genel internet verileri”, Erişim 7 Mart 2015, http://www.eticad.org.tr/bilgi-merkezi/sektorel-bilgiler/turkiye-genelinternet-verileri/ 